\title{
Occurrence, local extinction and conservation of Primates in the corridor of the Upper Paraná River, with notes on other mammals ${ }^{1}$
}

\author{
Lucas M. Aguiar ${ }^{2}$; Gabriela Ludwig ${ }^{2}$; Walfrido K. Svoboda ${ }^{3}$; \\ Carmen L. S. Hilst ${ }^{4}$; Italmar T. Navarro ${ }^{3} \&$ Fernando C. Passos ${ }^{2}$
}

\begin{abstract}
${ }^{1}$ Contribution number 1644 of the Departamento de Zoologia, Universidade Federal do Paraná.
${ }^{2}$ Laboratório de Biodiversidade Conservação e Ecologia de Animais Silvestres, Departamento de Zoologia, Universidade Federal do Paraná. Caixa Postal 19020,81531-980 Curitiba, Paraná, Brasil. E-mail: lucasmoraes@ufpr.br

${ }^{3}$ Laboratório de Protozoologia, Departamento de Medicina Veterinária Preventiva, Universidade Estadual de Londrina. Caixa Postal 6001, 86050-970 Londrina, Paraná, Brasil.

${ }^{4}$ Departamento de Clínicas Veterinárias, Centro de Ciências Agrárias, Universidade Estadual de Londrina, Caixa Postal 6001, 86051-990 Londrina, Paraná, Brasil.
\end{abstract}

\begin{abstract}
The region of Porto Rico, on the Upper Paraná River, is a contact zone between the Atlantic Rainforest and the Cerrado, with elements of the Pantanal wetlands. During surveys from September 2003 to September to 2005, we recorded the presence of non-volant mammals on 14 islands and the adjacent riverbanks. Surveys were by foot and by boat, and we also interviewed local people about the mammals of the region. Sightings of three primate species - Cebus nigritus (Goldfuss, 1809) (left margin of the river), C. libidinosus Spix, 1823 (right margin) and Alouatta caraya (Humboldt, 1812) (both margins and 12 islands) - were plotted on a satellite image. Alouatta clamitans Cabrera, 1940 was not recorded. However, interviews indicated that this species has occurred in this region in the past. The survey of mammals revealed the occurrence of 32 native species, a native genus with one or more unidentified species, and two introduced species [Lepus europaeus Pallas, 1778 and Sus scrofa (Linnaeus, 1758)]. The study discusses the permeability of the Paraná River to dispersal, as well as its potential as a geographical barrier to some species. Hypothesis on the local extinction of $A$. clamitans is also addressed. This study provides information that can be useful for promoting the conservation of this region. KEY WORDS. Exotic species; gallery forest; geographical barrier; neotropical primates.
\end{abstract}

RESUMO. Ocorrência, extinção local e conservação dos primatas do corredor do Alto Rio Paraná, com notas sobre outros mamíferos. A região de Porto Rico, Alto Rio Paraná, é zona de contato entre a Mata Atlântica e o Cerrado, com influências do Pantanal. Este estudo levantou as espécies de primatas da região para a confecção de um mapa de ocorrências. Listou-se as ocorrências de mamíferos não-voadores, discriminando os registros entre os ambientes de ilhas e margens opostas. Para tanto, além do auxílio de entrevistas, as matas de 14 ilhas e das margens foram percorridas por terra e de barco durante setembro de 2003 a setembro de 2005. Pontos de avistamento dos primatas foram plotados em imagem de satélite. Três espécies de primatas foram registradas: Cebus nigritus somente na margem esquerda do rio e em uma ilha próxima do continente; C. libidinosus somente na margem direita e Alouatta caraya em ambas as margens do rio e em 12 ilhas. Alouatta clamitans não foi encontrada, porém sua ocorrência passada foi registrada durante as entrevistas. O levantamento listou a ocorrência de 32 espécies nativas, um gênero com espécie(s) não identificada(s) e duas espécies introduzidas (Lepus europaeus e Sus scrofa). Este trabalho discute a permeabilidade do Rio Paraná para a dispersão e barreira geográfica para certas espécies. Hipóteses para a extinção de $A$. clamitans são discutidas. Este estudo promove informações úteis para a conservação da região.

PALAVRAS-CHAVE. Barreira geográfica; espécie exótica; floresta de galeria; primatas neotropicais.

The Paraná River runs for $4695 \mathrm{~km}$, with a drainage basin of $891,000 \mathrm{~km}^{2}$. Given its location and extension, the Paraná River plays an important ecological role in the distribution of the fauna and flora of the Atlantic Rainforest, Cerrado and Ama- zon biomes. Its gallery forests, as well as those of its important tributary, the Paraguay River, form an ecological connection for the exchange of biodiversity between the Atlantic and the western Amazon (Redford \& Fonseca 1986, Johnson et al. 1999).

Revista Brasileira de Zoologia 24 (4): 898-906, dezembro 2007 
In addition to their importance as dispersal corridors, the gallery forests of the large rivers have also served historically as biological refugia during drier periods (RANZI 2000). In an essentially arboreal environment such as the Atlantic Rainforest, the importance of the riparian environments as refuges is becoming increasingly evident. That is because the expansion of the agricultural and cattle frontiers have transformed these vegetational formations into a narrow mosaic confined to the river banks, surrounded by a matrix composed of pastures and agriculture. Due to these anthropic pressures, the corridors of riparian forests often remain as the only available habitats for the maintenance of forest species.

In addition to their importance as corridors and refugia, the role of large rivers in the speciation process is among the earliest hypotheses to explain the megadiversity found in tropical environments, particularly in the Amazon (WaLlace 1852 apud GASCON et al. 2000). It is currently known that large rivers might represent important dispersal restrictions to primates, thus serving as geographical barriers between the communities on opposite margins (but see review in FERRARI 2004). Therefore, rivers might determine the distributions and promote differentiation among primate taxa (Ayres \& Clutton-Brock 1992, Rylands et al. 1996, Patton et al. 2000, Silva-Júnior 2002, Ferrari 2004, Vilanova et al. 2005)

In western State of Paraná (PR) and eastern State of Mato Grosso do Sul (MS), in Brazil, the Upper Paraná River provides a geopolitical frontier, which coincides with the vegetational limits of the Atlantic Rainforest and the Cerrado, and is influenced by the Pantanal wetlands (Souza et al. 2004, Alho \& GonçaLVEs 2005). Despite its ecological importance, systematic surveys of primates and other mammals of the region are scarce, except for a few isolated studies (Tiepolo et al. 2004, Aguiar et al. 2005, 2007a, b, Corte et al. 2007, CUlLEN Jr et al. 2005, GARCiA et al. 2005, Ludwig et al. 2007, Rocha et al. 2007).

Therefore, the goal of the present study is to survey the current primate occurrences using a geographical information system to build an occurrence map for these animals in the region of Porto Rico, Upper Paraná River. In addition, a list of non-volant mammals of the region was composed, with separate records for island and mainland environments.

\section{MATERIAL AND METHODS}

\section{Study area}

The study area (Fig. 1) is located in the region of Porto Rico, northwest of Paraná, bordering the municipalities of Taquarussu and Baitaporã, in Mato Grosso do Sul, at $230 \mathrm{~m}$ above sea level. The region is named after the municipality of Porto Rico, which is encompassed by the following coordinates: $22^{\circ} 43^{\prime} 60^{\prime \prime} \mathrm{S}-53^{\circ} 24^{\prime} 18^{\prime \prime} \mathrm{W}, 22^{\circ} 46^{\prime} 42^{\prime \prime} \mathrm{S}-53^{\circ} 24^{\prime} 56^{\prime \prime} \mathrm{W}, 22^{\circ} 51^{\prime} 39^{\prime \prime} \mathrm{S}$ $53^{\circ} 19^{\prime} 45^{\prime \prime} \mathrm{W}$ and $22^{\circ} 57^{\prime} 14 S-52^{\circ} 16^{\prime} 5^{\prime \prime} \mathrm{W}$. It extends from the mouth of the Paranapanema River and the first connection between the Ivinhema and the Paraná rivers. In this region, the Paraná River varies between 1.5 and $5.0 \mathrm{~km}$ in breadth and is characterized by a system of fluvial archipelagos that tend to increase in number and size towards the mouth of the river (Souza Filho \& Stevaux 1997). In spite of the construction of several dams in the Paraná River and its tributaries, hydrometric levels still show seasonal variation, being highest between November and May and lowest between June and October, with sporadic floods. The climate in the region is humid subtropical with a warm summer, with an average annual rainfall between 1200 and 1300 mm (Romagnolo \& Souza 2000).

The vegetation in this region is classified as seasonal semideciduous forest with alluvial formations (flooded forests), which occur most commonly on the right margin and on the islands. The submontane formations that previously occurred in the region, particularly on the high terrain on the left margin of the river, are currently extinct (CAMPos \& SouzA 1997). Floristic surveys of the riparian forests indicate that the region is characterized by a low diversity of arboreal forests (SouzA et al. 2004). Human disturbance to these environments is severe since the 1960's (CAMPOS \& Souza 2003). Following the creation of the "Federal Area for Environmental Protection of the Islands and Flood Plains of the Paraná River" in 1997 (decree without number of September 30, 1997), the human populations living along the river banks were relocated and the neighboring pastures and plantations were purchased. Most of the arboreal vegetational formations in the region are in the process of regeneration.

\section{Methods}

The region of Porto Rico was monitored for two years, from September, 2003 to September, 2005. During the first year, several sporadic boat trips were carried out along the riparian forests in the river margins and islands of the Paraná River, Baía River, and the São Pedro Creek (right and left tributaries, respectively), searching for primates and other mammals. In the second year, boat trips were made for two weeks every month. In addition, the implementation of capture programs of primates and other free-living mammals (Aguiar et al. 2007b, RocHA et al. 2007), the ecological and behavioral monitoring of groups of primates in different environments and censuses along linear transects in islands, river margins and forest fragments completed the activities conducted during this period.

During these efforts, primate sightings were recorded using GPS (Global Positioning System) and plotted onto a LandSat satellite image using the software ArcView GIS 3.2a. to build the primate occurrence map.

A mammal checklist was also build along the observation period, to which were added interviews with other local researchers (J.M.D. Miranda and E. Carrano), residents and local hunters. The interview proceeded as follows: once we identified a mammal species through direct or indirect (footprints or feces) evidence, residents or local researchers were asked it they had seen another environment in the region where the respective species were recorded or hunted. The only two exceptions to this procedure were the precise identification of Alouatta clamitans Cabrera, 1940 and Chironectes minimus 


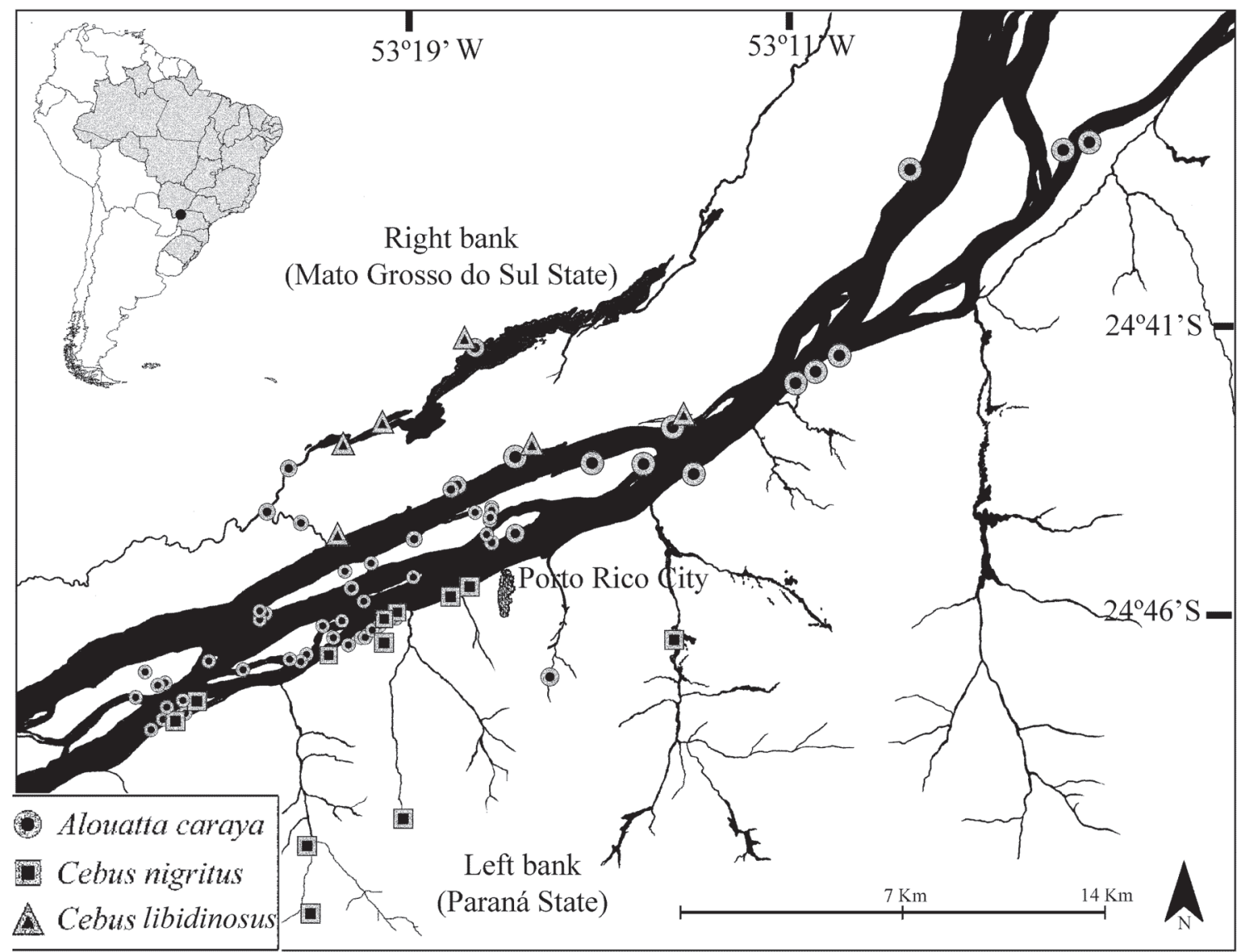

Figure 1. Porto Rico Region in the Upper Paraná River, Southern Brazil, with the occurrences of the Primate species.

(Zimmermann, 1780) by local residents. In these cases, the residents described precisely the size and coloration pattern of each species, as well as the aquatic environment of C. minimus. In general, this study followed the taxonomy proposed by WiLSON \& REEDER (2005), except for the genus Alouatta, which followed the taxonomy proposed by GREGORIN (2006).

\section{RESULTS}

\section{Primates}

Three species of primates were recorded in the region: Cebus nigritus (Goldfuss, 1809), C. libidinosus Spix, 1823 [C. cay (Illiger, 1815) sensu Silva-JúNIOR 2002] and A. caraya (Humboldt, 1812). Their occurrence records were plotted on the satellite image of the region (Fig. 1). Cebus nigritus occupies the riparian forests on the left margin of the Paraná River, as well as one of the two fluvial islands of the region (commonly known as the "Cortado" island), which is 15 to $30 \mathrm{~m}$ distant from the mainland. It was also recorded in the riparian forests of the São Pedro creek and in three forest fragments: the "Mata do Zezão", a 50 ha secondary forest belonging to the Fazenda Indiana $\left(22^{\circ} 50^{\prime} 45^{\prime \prime} \mathrm{S}\right.$ and $\left.53^{\circ} 18^{\prime} 16^{\prime \prime} \mathrm{W}\right)$, and in the two forest frag- ments known as "Mata do Guido Nogueira", each with 120 ha of disturbed primary forest belonging to the "Fazenda Divina

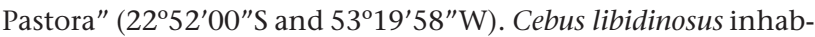
its the riparian forests of the dikes of the right margin of the Paraná River. It was also recorded on the right and left margins of two of its tributaries, the Baía and Curutuba rivers.

Alouatta caraya inhabits the riparian forests of both margins of the Paraná, Baía, and Curutuba rivers, as well as the São Pedro creek. In addition, this species was recorded on 12 of the 14 studied fluvial islands of the Paraná River varying from 5 to 1050 ha (the only two islands where it was not found were small and had their forests completely devastated), and in two forest fragments on the left margin that are close to the river (the "Mata do Zezão" described above, and a fragment with 30 ha).

The species A. clamitans, which could potentially be present at the study site, was not recorded throughout this study. However, there is a reliable record by a local resident that described a howler monkey specimen of an intense red coloration (possibly an adult male of $A$. clamitans), which traveled at a close distance from a group of black and gold howlers (A. caraya) in the riparian forests of the Japonesa Island, approximately 10 years ago. 
In conclusion, the continental environments included two species in each opposite margin. On the left margin, A. caraya is sympatric to $C$. nigritus, whereas on the right margin $A$. caraya is sympatric with C. libidinosus. Island environments that are isolated from the continent had only one species, $A$. caraya, which accounted for $50 \%$ of the primate richness species present in any of the two continental environments.

\section{Notes on other mammals}

A total of 32 native species of non-volant mammal were recorded, as well as one or more unidentified species of the genus Mazama Rafinesque, 1817, and two introduced species [Lepus europaeus Pallas, 1778 and Sus scrofa (Linnaeus, 1758)]. These species are distributed among 31 genera, 15 families, and nine orders. Table I indicates the occurrences according to the nature and habitat of the records, as well as whether the respective species was under hunting pressure in the region.

\section{DISCUSSION}

\section{Primates}

The recorded species indicate that, in the case of the order Primates, the region of the Upper Paraná River can be considered as a zone of faunistic contact, reflecting the vegetational limits between the Cerrado and the Atlantic Rainforest, including and influence of the Pantanal (SouzA et al. 2004, AlHo $\&$ Gonçalves 2005). For instance, $A$. caraya is a howler species that is characteristic of Central Brazil, occurring mainly within the limits of the Cerrado, where it is usually found in gallery forest formations and semideciduous forests (RYLANDs et al. 1996, Gregorin 2006). Together with Northeastern Argentina, the western region of the Southern Brazilian states is considered an area of sympatry between $A$. caraya and A. clamitans, which is characteristic of the south and southeastern portion of the Atlantic Rainforest. These two species have mostly parapatric distributions, with sympatry regions along the Paraná and Uruguay rivers (Hirsch et al. 1991, Di BitetTi et al. 1994, Gregorin 2006, Aguiar et al. 2007a).

Although the efforts of the present study have failed to locate A. clamitans in the region of Porto Rico, the record of a local resident that clearly described an adult male of this species is clear evidence of its occurrence in the past decade. In addition, the specimens of $A$. clamitans, $A$. caraya and their possible hybrids collected by André Mayer during the 1940's and 1950's were obtained in municipalities in the vicinity of Porto Rico, in a region known as "Sertão do Rio Paraná" which includes a nearly $30 \mathrm{~km}$ stretch of the Paraná River between the municipalities of São Pedro do Paraná e Guairá (PR) (Lorin \& Persson 1990, Gregorin 2006), that also includes Porto Rico. At that time, primates were also collected in Porto São José, in the municipality of São Pedro do Paraná, which is adjacent to Porto Rico, upstream of the Paraná River. This site is located on the left margin of the Paraná River, around $11 \mathrm{~km}$ of Porto Rico and $10 \mathrm{~km}$ of the mouth of the Paranapanema River, where both $A$. clamitans and $A$. caraya still coexist (L.M. Aguiar, personal observation). Specimens of A. clamitans were also collected in Querência do Norte, another municipality adjacent to Porto Rico downstream of the Paraná River (HiRsCh et al. 1991, GREGORIN 2006). Also downstream of Porto Rico, more precisely in the Ilha Grande National Park, A. clamitans is still found in the Submontana Semideciduous Seasonal Forest in sympatry with A. caraya (Aguiar et al. 2007b). All this evidence lead to the hypothesis that A. clamitans was indeed sympatric with $A$. caraya in the region of Porto Rico. It was later extinct and is currently absent from this stretch of the Paraná River. Alouatta clamitans could be associated with the Submontane Semideciduous Seasonal Forest that is currently extinct in this region.

Reviews and studies in Argentina (Di BiтEтTI et al. 1994, Сrocкетт 1998) appear to indicate that $A$. clamitans prefers moist forests, being mostly found in continuous formations of the Brazilian Atlanic Rainforest. According to these authors, the populations of $A$. caraya seem less affected by fragmentation and therefore could replace $A$. clamitans in some sectors of its geographical distribution. Thus, the presence and use of marginal habitats by $A$. caraya can be a good indication of its degree of flexibility to extreme conditions (BICCA-MARQUES 1994), suggesting that this species does not have the same degree of vulnerability as its congener, A. clamitans. Possibly, the relative sensitivity to environmental anthropic influence of $A$. clamitans has contributed for this species to be unable to survive in this portion of the river, which is currently heavily disturbed.

The problem of anthropization of natural biotypes can represent a conditioning element to the loss of biodiversity, as well as epizootic outbreaks and local epidemics (Avila-Pires 2000). Zoonosis monitoring studies on the primates of the region of Porto Rico have shown that $A$. caraya shows high levels of parasite infestation, and some diseases can reduce considerably portions of their populations during the host-parasite cycles, including helminthosis, nematodiasis, toxoplasmosis, leptospirosis, paracoccidiomycosis, oropouche and Saint Louis encephalitis (CORTE et al. 2007, GArCia et al. 2005). From this point of view, an additional argument can be raised to explain the local extinction of $A$. clamitans: this species might be more sensitive to high parasitary loads and more susceptible to epizootic events than $A$. caraya. Given the considerable parasite load of A. caraya at the regional level, and the historical record of yellow fever in the region of Porto Rico (CARMo et al. 2001), one could imagine that past outbreaks could have contributed to the populational reduction or extinction of $A$. clamitans in the region of Porto Rico.

In relation to the occurrence of species of the genus Cebus Erxleben, 1777, the region of Porto Rico also represents a contact zone, limiting the distribution of species that are characteristic of Central Brazil (C. libidinosus) or the Atlantic Rainforest (C. nigritus). Cebus libidinosus and C. nigritus display contiguous distributions, being allopatric along the Paraná River (SILVAJúNIOR 2002, VILANOVA et al. 2005). 
Table I. Checklist of non-volant mammals of the region of Porto Rico, specifying the records on Islands or on opposite margins of the Upper Paraná River, as well as those species under hunting pressures: 34 species (32 natives and two introduced) and one genus with one or more unidentified species, distributed among 30 genera, 15 families and nine orders. (O) Observation, (T) track, (I) interview, (HP) hunting pressure.

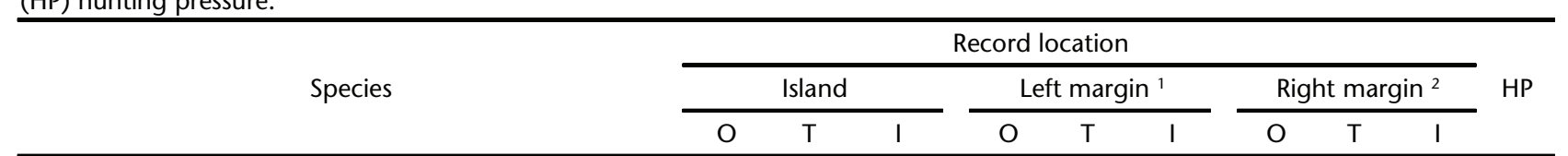

Didelphimorphia

Didelphis albiventris (Lund, 1840)

Didelphis aurita (Wied-Neuwied, 1826)

$x$

$\underline{x}$

Chironectes minimus (Zimmermann, 1780)

Cingulata

Dasypus novencinctus (Linnaeus, 1758)

Dasypus septemcinctus (Linnaeus, 1758)

Euphractus sexcinctus (Linnaeus, 1758)

Pilosa

Tamandua tetradactyla (Linnaeus, 1758)

Myrmecophaga tridactyla (Linnaeus, 1758)

Primates

Alouatta caraya (Humboldt, 1812)

Cebus nigritus (Goldfuss, 1809)

Cebus libidinosus Spix, 1823

Carnivora

Nasua nasua (Linnaeus, 1766)

Procyon cancrivorus (G. Cuvier, 1798)

Galictis cuja (Molina, 1782)

Lontra longicaudis (Olfers, 1818)

Cerdocyon thous (Linnaeus, 1766)

Leopardus tigrinus (Schreber, 1775)

Leopardus pardalis (Linnaeus, 1758)

Puma yagouaroundi (É. Geoffory Saint-Hilare, 1803)

Puma concolor (Linnaeus, 1771)

Panthera onca (Linnaeus, 1758)

Perissodactyla

Tapirus terrestris (Linnaeus, 1758)

Artiodactyla

Mazama sp.

Blastocerus dichotomus (Illiger, 1815)

Pecari tajacu (Linnaeus, 1758)

Tayassu pecari (Link, 1795)

Sus scrofa (Linnaeus, 1758) *

$x$

$\mathrm{x}$

$\mathrm{x}$

$\mathrm{x}$

$\mathrm{x}$

$x$

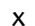

$\underline{x}$

$x$

$x$

x

X

X

$x$

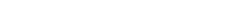

$\mathrm{x}$

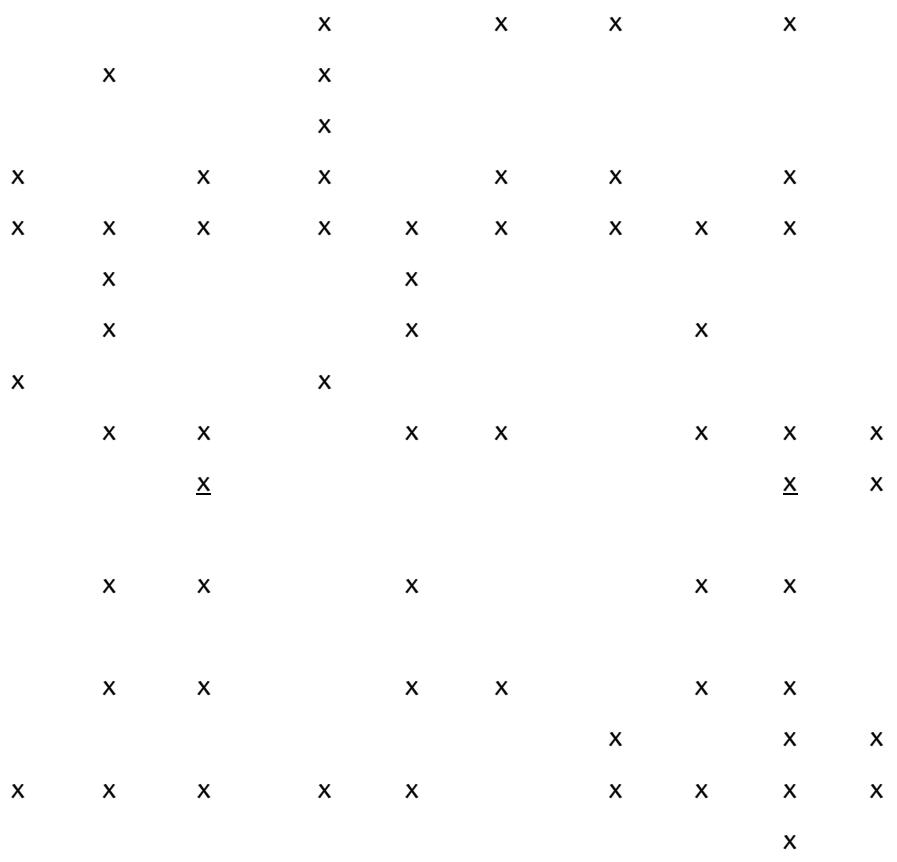


Table I. Continued.

\begin{tabular}{|c|c|c|c|c|c|c|c|c|c|c|}
\hline \multirow{3}{*}{ Species } & \multicolumn{9}{|c|}{ Record location } & \multirow{3}{*}{ HP } \\
\hline & \multicolumn{3}{|c|}{ Island } & \multicolumn{3}{|c|}{ Left margin ${ }^{1}$} & \multicolumn{3}{|c|}{ Right margin $^{2}$} & \\
\hline & $\mathrm{O}$ & $\mathrm{T}$ & I & $\mathrm{O}$ & $\mathrm{T}$ & 1 & $\mathrm{O}$ & $\mathrm{T}$ & I & \\
\hline \multicolumn{11}{|l|}{ Rodentia } \\
\hline Cavia aperea (Erxleben, 1777) & & & $x$ & $x$ & & & & & & \\
\hline Dasyprocta azarae Lichtenstein, 1823 & $x$ & $x$ & $x$ & $x$ & $x$ & $x$ & $x$ & $x$ & $x$ & $\mathrm{x}$ \\
\hline Cuniculus paca (Linnaeus, 1758) & & & $x$ & & & $x$ & & & & $x$ \\
\hline Sphiggurus villosus (F. Cuvier, 1823) & & & $x$ & $x$ & & & & & & \\
\hline Myocastor coypus (Molina, 1782) & & & & $x$ & & & & & & \\
\hline Hydrochoerus hydrochaeris (Linnaeus, 1766) & $x$ & $x$ & $x$ & $x$ & $x$ & $x$ & $x$ & $x$ & $x$ & $x$ \\
\hline \multicolumn{11}{|l|}{ Lagomorpha } \\
\hline Lepus europaeus Pallas, 1778 * & & & & $x$ & & & & & & \\
\hline Sylvilagus brasiliensis Gray, 1867 & & & & & & $\underline{x}$ & & & & \\
\hline Total & & 25 & & & 27 & & & 20 & & 11 \\
\hline
\end{tabular}

${ }^{1}$ State of Paraná, Brazil; ${ }^{2}$ State of Mato Grosso do Sul, Brazil; ${ }^{*}$ exotic species; $(\underline{x})$ observation and personal communication of others researchers.

Contrary to the situation in A. caraya, the occurrence of the genus Cebus in the region is restricted only to the continental environments of the Paraná River, with this river forming a geographical barrier (SILVA-JÚNIOR 2002, VILANOva et al. 2005). In Porto Rico, C. nigritus was found only on one island (Region of Cortado), which is very close to the continent. The animals could have reached it by the "bridges" formed by the tree tops or even on foot during the dry periods, without the need of swimming.

\section{Notes on other mammals}

The present list of mammals indicates that the region of Porto Rico is a point of overlap between the mammal faunas of neighboring areas (e.g. Atlantic Rainforest, Cerrado, and Pantanal; see RedFord \& Fonseca 1986, Alho et al. 1988, Schneider et al. 2000, Margarido \& Braga 2004, Alho \& Gonçalves 2005). On the other hand, it also suggests that the permeability of the Paraná River as a dispersal barrier varies according to the species in question. One can infer that the mammals recorded on island environments have the capacity to disperse by swimming between the river margins and the islands. Alouatta caraya, Hydrochoerus hydrochaeris (Linnaeus, 1766), Euphractus sexcinctus (Linnaeus, 1758), Pecari tajacu (Linnaeus, 1758), Panthera onca (Linnaeus, 1758) and Puma yaguarondi (É. Geoffory Saint-Hilare, 1803) have already been observed swimming on the main channel of the Paraná River and one of its tributaries, the Baía River, by our field assistant (A. B. SECORUn personal communications). Chironectes minimus, Puma concolor (Linnaeus, 1771), Lontra longicaudis (Olfers, 1818) and Tapirus terrestris (Linnaeus, 1758) are present in the island environments and they are known hydrophyles and could therefore cross the river by swimming.
This capacity has been also recorded by the genus Didelphis (Linnaeus, 1758) (E. L. A. Monteiro-Filho personal communication) and for Myocastor coypus (Molina, 1782).

However, the known absence of three species [C. nigritus, C. libidinosus, and Nasua nasua (Linnaeus, 1766)] from the island environments, as well as the absence of records of these species swimming, seems to indicate that the Paraná River can work as a geographical barrier for their dispersal. In the case of the remaining species, the available data are not sufficient for their discussion.

The list reported in this study shows several species that are officially considered as threatened. Twelve of the 34 recorded species are considered as threatened according to the current Checklist of Endangered Species of the State of Paraná (MARgarido \& Braga 2004): A. caraya, Cuniculus paca (Linnaeus, 1758), Myrmecophaga trydactyla (Linnaeus, 1758), Tayassu pecari (Link, 1795), P. tajacu, Blastocerus dichotomus (Illiger, 1815), T. terrestris, L. longicaudis, Leopardus tigrinus (Schreber, 1775), L. pardalis (Linnaeus, 1758), P. concolor and $P$. onca. In addition, according to this list, two species have been ranked as of unknown status due to insufficient information on their biology: C. minimus and Dasypus septemcinctus (Linnaeus, 1758). At the national level, according to the Brazilian Checklist of Endangered Species (MACHADO et al. 2005), six of the species are considered as being under risk of extinction: M. trydactla, $B$. dichotomus, L. pardalis, L. tigrinus, P. concolor, and P. onca.

Some mammals of the region are under strong pressure from food and sport hunting. Dasypus spp., Dasyprocta azarae Lichtenstein, 1823, C. paca, H. hydrochaeris, T. pecari are hunted for food by local residents. Blastocerus dichotomus, P. concolor 
and $P$. onca are hunted as game. Also, large felids are shot due to attacks on domestic animals. Cebus species are also shot because they are seen by farmers are pests when they feed on their crops.

\section{Perspectives for conservation}

In addition to the frequent hunting, other pressures such as the selective cut of trees, the opening of roads, habitat loss, apiculture, threading by cattle, the introduction of exotic species, the draining of flooding plains for pastures, domestic waste, and unsustainable tourism are present in the natural habitats of this portion of the Paraná River, thus contributing for the perturbation of this ecosystem.

Many of these anthropic influences described above have already been pointed out as interdependent and causal to the environmental degradation of other sensitive ecosystems that experience periodical floodings, such as the Ilha Grande National Park in the Paraná River and the Pantanal wetlands (AlHo et al. 1988, Tiepolo et al. 2004, Alho \& Gonçalves 2005).

In the case of the Pantanal, AlHo et al. (1988) already underscored the impact of introduced species, such as $S$. scrofa, through predation and competition with native species. This species also has been causing environmental problems in Brazil and in other South American countries such as Chile and Argentina (Jaksic et al. 2002, Moura-BritTo \& PATrocínio 2006). In addition, feral beasts also generate another environmental problem to natural habitats: the frequent stomping can interfere directly on the quality of the forests, preventing the recruitment of natural plants (CAmpos \& Souza 2003). In some islands in the region of Porto Rico (e.g. Porto Rico, Carioca, and Mutum islands), the occurrence and the impact caused by the introduction of S. scrofa is well known by the environmental protection agencies, yet not study, management effort or means of population control has been implemented to date.

Another species that has been introduced to Brazil and is present in the region of Porto Rico is L. europaeus. It is abundant in the PR and São Paulo State and countries such as Chile, Argentina, and North America, where it is considered as a pest species for exploiting pastures and crops (Auricchio \& Olmos 1999, Jaksic et al. 2002, Moura-Britto \& Patrocínio 2006). According to these authors, it is likely that $L$. europaeus competes with native species. In the case of Porto Rico, its interaction with the native Sylvilagus brasiliensis Gray, 1867 is a cause of particular concern. Studies on the impact of $L$. europaeus in natural ecosystems in the region of Porto Rico are absent and deserve particular attention and support.

In addition to the two introduced mammal species described above, little is known about the impact of Apis mellifera (Linnaeus, 1758) in the region, and studies on this topic are inexistent. Apiculture has been increasing in the region due to the support from the Serviço Brasileiro de Apoio às Micro e Pequenas Empresas (SEBRAE), which was followed by environmental degradation, impacting native species and clearing forest areas for its implementation. Tiepolo et al. (2004) investi- gated the impact of apiculture on the population of $B$. dichotomus in the Ilha Grande National Park, with death records of these animals following attacks by $A$. mellifera. In Porto Rico, data from this study as well as others indicate that groups of $A$. caraya and $C$. nigritus tend to avoid regions of their home ranges with bee rearing boxes that are suspended on the vegetation at various heights. These areas often have habitat quality levels that are equal or higher than those that are actually used by the groups (L.M. Aguiar personal observation). Therefore, a growing apiculture activity in the region with governmental support without previous studies on the environmental impacts of such activity raises special concern.

Other factors also need to be taken into account. For instance, human populations still persist illegally in the river islands, and should be relocated by governmental authorities. According to the interviews, these populations are the source of most of the hunting activities in the region. The cattle that illegally occupies riparian forests should be removed and the respective owners should be fined. The construction of houses, opening of roads, pastures and tourist camping locations should be prohibited. Public policies should not only foster, but also ensure that riparian forests are recovered, at least to connect local forests. These are some of the problems that suggest that current officials should pay more attention to the terrestrial ecosystems of the region. Therefore, it is fundamental to organize efficient local authorities in the region of Porto Rico, as well as studies aiming at evaluating priority areas in this region to be designated as Conservation Units (CUs).

\section{ACKNOWLEDGMENTS}

To CNPq, CAPES, SESA/PR (Secretaria de Estado da Saúde), Adilson B. Secorun, Valmir O. da Silva, Luciano S. Malanski, Natal Jataí, Lineu R. Silva, Ângela M. Mello, Ricardo Matsuo, Gonçalves Beletato, Edílson C. Colhera, José L. Filho, José P. dos Santos. Adriano G. Chiarello, Zelinda M.B. Hirano, Emydgio L.A. Monteiro-Filho, João M.D. Miranda and two reviwers provided helpfull sugestions.

\section{REFERENCES}

Aguiar, L.M.; G. Ludwig; C.L.S. Hilst; L.S. Malanski \& F.C. Passos. 2005. Tentativa de infanticídio por um macho dominante de Alouatta caraya (Humboldt) (Primates, Atelidae) em um infante extra-grupo devido a influência do observador. Revista Brasileira de Zoologia 22 (4): 1201-1203.

Aguiar, L.M.; D.M. Mellek; C.C. Abreu; T.G. Boscarato; I.P. Bernardi; J.M.D. Miranda \& F.C. Passos. 2007a. Sympatry of Alouatta caraya and Alouatta clamitans and the rediscovery of free-ranging potential hybrids in Southern Brazil. Primates 48 (2): 245-248.

Aguiar, L.M.; G. Ludwig; W.K. Svoboda; G.M. Teixiera; M.M. Shiozana; L.S. Malanski; A.M. Mello; I.T. Navarro \& F.C. Passos. 2007b. Use of traps to capture Black and Gold Howlers (Alouatta caraya) in the islands of the upper Paraná river, 
Southern Brazil. American Journal of Primatology 69 (2): 241-247.

Alho, J.R. \& H.C. Gonçalves. 2005. Biodiversidade do Pantanal: ecologia e conservação. Campo Grande, Editora Unerp, $143 p$.

Alho, C.J.R.; T.E. Lacher JR; Z.M.S. Campos \& H.C. Gonçalves. 1988. Mamíferos da Fazenda Nhumirim, sub-região de Nhecolândia, Pantanal do Mato Grosso do Sul: levantamento preliminar de espécies. Revista Brasileira de Biologia 48 (2): 213-255.

Auricchio, P. \& F. Olmos. 1999. Northward range extension for the european hare, Lepus europaeus Pallas, 1778 (Lagomorpha - Leporidae) in Brazil. Publicações Avulsas do Instituto Pau Brasil (2): 1-5.

Avila-Pires, F.D. 2000. Princípios de ecologia médica. Florianópolis, Editora da UFSC, 328p.

Ayres, J.M. \& T.H. ClutTon-Brock. 1992. River boundaries and species range size in Amazonian Primates. American Naturalist 140 (3): 531-537.

Bicca-Marques, J.C. 1994. Padrão de utilização de uma ilha de mata por Alouatta caraya (Primates: Cebidae). Revista Brasileira de Biologia 54 (1): 161-171.

Campos, J.B. \& M.C. Souza. 1997. Vegetação, p. 331-342. In: A.E.A.M. Vazzoler; A.A. Agostinho \& N.S. Hahn (Eds). A Planície de Inundação do Alto Rio Paraná: aspectos físicos, biológicos e socioeconômicos. Maringá, EDUEM Nupélia, 460p.

Campos, J.B. \& M.C. Souza. 2003. Potencial for natural Forest regeneration from seed bank in an Upper Paraná River Floodplain, Brazil. Brazilian Archives of Biology and Technology 46 (4): 625-639.

Carmo, E.H.; E.S.O. Araújo; E. Martins; H. Pelludi; M.L.S. Maia; M.G. Almeida; R. Dusi; R. Dubor \& Z. GuerRa. 2001. Situação atual da febre amarela no Brasil. Boletim Eletrônico Epidemiológico FUNASA 1 (2): 1-11.

Corte, A.C.; W.K. Svoboda; I.T. Navarro; R.L. Freire; L.S. Malanski; M.M. Shiozawa; G. Ludwig; L.M. Aguiar; F.C. Passos; A. Maron; Z.P. Camargo; E.N. Itano \& M.A. Ono. 2007. Paracoccidioidomycosis in wild monkeys from Paraná State, Brazil. Mycopathologia 164 (5): 225-228.

Crockett, C.M. 1998. Conservation biology of the genus Alouatta. International Journal of Primatology 19 (3): 549578.

Cullen, L. JR; C.C. Abreu; D. Sana \& A.F.D. NAvA. 2005. Jaguars as landscape detectives for the upper Paraná River corridor, Brazil. Natureza e Conservação 3 (1): 147-161.

Di Bitetti, M.S.; G. Placci; A.D. Brown \& D.I. Rode. 1994. Conservation and population status of the brown howling monkey (Alouatta fusca clamitans) in Argentina. Neotropical Primates 2 (4): 1-4.

Ferrari, S.F. 2004. Biogeography of Amazonian primates, p. 101122. In: S.L. Mendes \& A.G. Chiarello (Eds). A Primatologia no Brasil 8. Vitória, IPEMA/SBPr, 340p.
Garcia, J.L.; W.K. Svoboda; A.L. Chryssafidis; L.S. Malanski; M.M. Shiozawa; L.M. Aguiar; G.M. Teixeira; G. Ludwig; L.R. Silva; C.L.S. Hilst \& I.T. Navarro. 2005. Sero-epidemiological survey for toxoplasmosis in wild New World monkeys (Cebus spp.; Alouatta caraya) at the Paraná river basin, Paraná state, Brazil. Veterinary Parasitology 133: 307-311.

Gascon, C.; J.R. Malcolm; J.L. Patton; M.N.F. Silva; J.P. Bogart; S.C. Lougheed; C.A. Peres; S. Neckel \& P.T. Boag. 2000. Riverine barriers and the geographic distribution of Amazonian species. Proceedings of the National Academy of Sciences 97 (25): 13672-13677.

Gregorin, R. 2006. Taxonomia e variação geográfica das espécies do gênero Alouatta Lacépède (Primates, Atelidae) no Brasil. Revista Brasileira de Zoologia 23 (1): 64-144.

Hirsch, A.; E.C. Landau; A.C.M. Tedeschi \& J.O. Menegheti. 1991. Estudo comparativo das espécies do gênero Alouatta Lacèpéde, 1799 (Platyrrhini, Atelidae) e sua distribuição geográfica na América do Sul, p. 239-262. In: A.B. RyLANDS \& A.T. Bernardes (Eds). A Primatologia no Brasil 3. Belo Horizonte, SBPr/Fundação Biodiversitas, 459p.

Jaksic, F.M.; J.A. Iriarte; J.E. Jiménez \& D.R. Martínez. 2002. Invaders without frontiers: cross-border invasions of exotic mammals. Biological Invasions 4: 157-173.

Johnson, M.A.; P.M. Saraiva \& D. Coelho. 1999. The role of gallery forests in the distribution of Cerrado mammals. Revista Brasileira de Biologia 59 (3): 421-427.

Lorini, M.L. \& V.G. Persson. 1990. A contribuição de André Mayer a História Natural no Paraná (Brasil). II Mamíferos do Terceiro Planalto Paranaense. Arquivos Brasileiros de Biologia e Tecnologia 32 (1): 117-132.

Ludwig, G.; L.M. Aguiar; J.M.D. Miranda; G.M. Teixeira; L.S. Malanski; M.M. Shiozana; C.L.S. Hilst; I.T. Navarro \& F.C. PAssos. 2007. Cougar predation on black-and-gold howlers at Mutum Island, Southearn Brazil. International Journal of Primatology 28 (1): 39-46.

Machado, A.B.M.; C.S. Martins \& G.M. Drummond. 2005. Lista da Fauna Brasileira Ameaçada de Extinção: incluindo as espécies quase ameaçadas e deficientes em dados. Belo Horizonte, Fundação Biodiversitas, 160p.

Margarido, C.C. \& F.G. Braga. 2004. Mamíferos, p. 27-142. In: S.B. Mikish \& R.L. BérniLs (Eds). Livro vermelho da fauna ameaçada no estado do Paraná. Curitiba, Governo do Paraná/SEMA/IAP, 763p.

Moura-Britto M. \& D.N.M. Patrocínio. 2006. A fauna de espécies exóticas no Paraná: contexto nacional e situação atual, p. 53-94. In: J.B. CAmpos; M.G.P. Tossulino \& C.R.C. MulleR (Eds). Unidades de Conservação, ações para valorização da biodiversidade. Curitiba, IAP, 348p.

Patton J.L.; M.N.F. Silva \& J.R. Malcolm. 2000. Mammals of the Rio Juruá and the evolutionary and ecological diversification of Amazonia. Bulletin of the American Museum of Natural History 244: 1-306.

Ranzi, A. 2000. Paleoecologia da Amazônia: megafauna do 
Pleistoceno. Florianópolis, Editora UFSC, 101p.

RedFord, K.H. \& G.A.B. FonseCA. 1986. The role of gallery forests in the Zoogeography of the Cerrado's non-volant mammalian fauna. Biotropica 18 (2): 126-135.

Rocha, V.J.; L.M. Aguiar; G. Ludwig; C.L.S. Hilst; M.M. Shiozawa; L.S. Malanski; I.T. Navarro; J.H.F. Mariño \& F.C. Passos. 2007. Techniques and trap models for capturing wild tufted capuchins. International Journal of Primatology 28 (1): 231-243.

Romagnolo, M.B. \& M.C. Souza. 2000. Análise florística e estrutural de florestas ripárias do alto rio Paraná, Taquaruçu, MS. Acta Botânica Brasilica 14 (2): 163-174.

Rylands, A.B.; G.A.B. Fonseca; Y.L.R. Leite \& R.A. Mittermeier. 1996. Primates of the Atlantic Forest: origins, distributions, endemism, and communities, p. 21-51. In: M.A. Norconk; A.L. Rsenberger \& P.A. Garber (Eds). Adaptative radiations of Neotropical Primates. New York, Plenum Press, 553p.

Schneider, M.; A.A.B. Marques; R.S.S. Lima; C.P. Nogueira; R.C. Printes \& J.A.S. Silva. 2000. Lista atualizada dos mamíferos encontrados no Parque Nacional da Serra da Canastra (MG) e arredores, com comentários sobre as espécies. Biociências 8 (2): 3-17.

SiLVA-Júnior, J.S. 2002. Taxonomy of capuchin monkeys, Cebus
Erxleben, 1777. Neotropical Primates 10 (1): 29.

Souza, M.C.; M.B. Romagnolo \& K.K. Kita. 2004. Riparian vegetation: ecotones and plant communities, p. 353-367. In: S.M. Thomaz; A.A. Agostinho \& N.S. Hahn (Eds). The Upper Paraná River and its floodplain: physical aspectcs, ecology and conservation. Leiden, Backhuys Publishers, 393p.

Souza Filho, E.E. \& J.C. Stevaux. 1997. Geologia e geomorfologia do complexo rio Baía, Curutuba, Ivinheima, p. 3-46. In: A.E.A.M. Vazzoler; A.A. Agostinho \& N.S. Hahn (Eds). A Planície de Inundação do Alto Rio Paraná: Aspectos físicos, biológicos e socioeconômicos. Maringá, EDUEM Nupélia, 460p.

Tiepolo, L.M.; F.A.Z. Fernandez \& W.M. Tomas. 2004. A conservação da população de cervo-do-pantanal Blastocerus dichotomus (Illiger, 1815) (Mammalia, Cervidae) no Parque Nacional de Ilha Grande e entorno (PR/MS). Natureza e Conservação 2 (1): 56-66.

Vilanova, R.; J.S. Silva-Júnior; C.E.V. Grelle; G. Marroig \& R. Cerqueira. 2005. Limites climáticos e vegetacionais das distribuições de Cebus nigritus e Cebus robustus (Cebinae, Platyrrhini). Neotropical Primates 13 (1): 14-19.

Wilson, D.E. \& D.M. ReEder. 2005. Mammal species of the world. Baltimore, Johns Hopkins University Pres, 2142p.

Received in 05.II.2007; accepted in 12.XI.2007. 